\title{
Studi Nilai dan Distribusi Biodiversitas di Daerah Aliran Sungai (DAS) Ciliwung Hulu
}

\author{
SRY WAHYUNI ${ }^{1 *}$, SYARTINILIA ${ }^{1}$ \\ ${ }^{1}$ Departemen Arsitektur Lanskap, Fakultas Pertanian, Institut Pertanian Bogor \\ Jalan Meranti, Dramaga, Bogor 16680, Indonesia \\ *E-mail: srywahyuniii@gmail.com
}

\section{ABSTRACT \\ Study of Biodiversity Value and Distribution in The Upper Stream of Ciliwung Watershed}

Watershed is one of the ecological boundary that has important role related to landscape sustainability. Ciliwung Watershed is categorized as super-priority watershed in Indonesia and provides landscape services particularly mentioned in this study is biodiversity value.The study sites were located in three sub-districts in the upper stream of Ciliwung Watershed (Ciawi, Megamendung, Cisarua), Bogor District of West Java. The main objectives of this study were to analyze value and distribution of biodiversity using six indicators of landscape sustainability. The six indicators (presence of threatened species, land use and land cover change, land use intensity of organic agricultural, population, occupation, and infrastructure) were analyzed using geographical information system (GIS). Based on the result, it can be shown that Cisarua and Megamendung sub-district are the first and second largest area with high biodiversity value $(4.022 \mathrm{Ha}$ and $2.099 \mathrm{Ha})$. Meanwhile, Ciawi sub-district has no area with high biodiversity value. Finally, we propose six recomendations of landscape management for biodiversity sustainability in the upper stream of Ciliwung Watershed.

Keywords:biodiversity value, Ciliwung Watershed, landscape service, GIS, landscape management

\section{Pendahuluan}

Daerah aliran sungai (DAS) merupakan suatu sistem dimana semua komponen penyusunnya saling berinteraksi khususnya antara hulu dengan hilir. Terjadinya gangguan salah satu komponen tersebut menyebabkan gangguan pada keseluruhan sistem (Sutopo, 2001).Sebagai salah satu ekosistem DAS, Ciliwung merupakan salah satu DAS yang tergolong kritis. Meningkatnya konversi lahan terbuka menjadi lahan terbangun untuk berbagai kebutuhan seperti perumahan, industri, pariwisata, dan prasarana lainnya dengan tidak berlandaskan pengetahuan tentang lingkungan mengakibatkan perubahan yang sangat drastis pada ekosistem DAS Ciliwung, terutama wilayah hilir. Wilayah hilir 
DAS Ciliwung yang mencakup daerah Jakarta merupakan Ibukota negara dimana banyak terdapat aset nasional dan juga pusat pemerintahan negara Indonesia.

Lanskap merupakan suatu bagian ruang pada muka bumi dengan sistem kompleks dalam bentuk aktivitas komponen biotik dan abiotik. Sementara lingkungan merupakan kombinasi antara komponen biotik dan abiotik. Terdapat persamaan antara lanskap dan lingkungan, yaitu adanya interaksi dan hubungan timbal balik antara komponen biotik dan abiotik yang menghasilkan suatu jasa dari proses ekologis komponen-komponen di dalamnya. Jasa lanskap belum mendapat apresiasi secara luas sementara fungsifungsinya semakin terganggu akibat adanya perubahan penggunaan pada lanskap tersebut. DAS Ciliwung hulu merupakan suatu ekosistem yang memberikan jasa lanskap terhadap wilayah sekitarnya, yaitu berupa jasa pengaturan tata air, keanekaragaman hayati, penyerapan karbon, dan keindahan lanskap (RUPES, 2009).

Indonesia merupakan negara megabiodiversitas dengan keanekaragaman hayati yang sangat tinggi. Biodiversitas memiliki enam nilai penting, yaitu eksistensi, jasa lanskap, warisan, pilihan, konsumtif, dan produktif (BAPPENAS, 2004). Menurut Turner et al. (1999) dalam Nunes et al. (2003), biodiversitas memiliki empat level, yaitu gen, spesies, ekosistem, dan fungsi. Keberadaan spesies terancam (threatened species) dapat digunakan sebagai indikator untuk menilai biodiversitas karena mampu menggambarkan kondisi biodiversitas secara keseluruhan yang terdapat pada suatu area tertentu (Williams et al. 2000 dalam Curry dan Humphries 2007). Menurut Nunes et al. (2003) dan Verburg et al. (2011), indikator yang berpengaruh terhadap keberlanjutan biodiversitas adalah aktivitas dan jumlah penduduk yang berimplikasi pada perubahan penutupan dan penggunaan lahan, intensitas penggunaan lahan pertanian, pekerjaan penduduk, dan pembangunan infrastruktur.

Untuk menjaga keberlanjutan biodiversitas tersebut, perlu dilakukan suatu studi identifikasi nilai biodiversitas sebagai penyedia jasa lanskap. Hal ini dapat dilakukan dengan melihat kondisi penutupan lahan dan distribusi ruang terbuka yang terdapat di DAS Ciliwung Hulu dengan memanfaatkan teknologi Sistem Informasi Geografi (SIG). Data yang dihasilkan digunakan untuk menyusun rekomendasi pengelolaan biodiversitas di DAS tersebut agar keberlanjutan dan kelestariannya tetap terjaga.

\section{Metode}

\subsection{Waktu dan Lokasi Penelitian}

Penelitian ini dilaksanakan dari bulan Maret sampai Desember 2013 yang meliputi tahap inventarisasi, analisis biodiversitas, dan sintesis berupa penyusunan rekomendasi pengelolaan biodiversitas. Studi biodiversitas ini dilaksanakan di tiga kecamatan yang terletak pada DAS Ciliwung Hulu, Kabupaten Bogor. Ketiga kecamatan tersebut adalah Kecamatan Ciawi, Megamendung, dan Cisarua. 

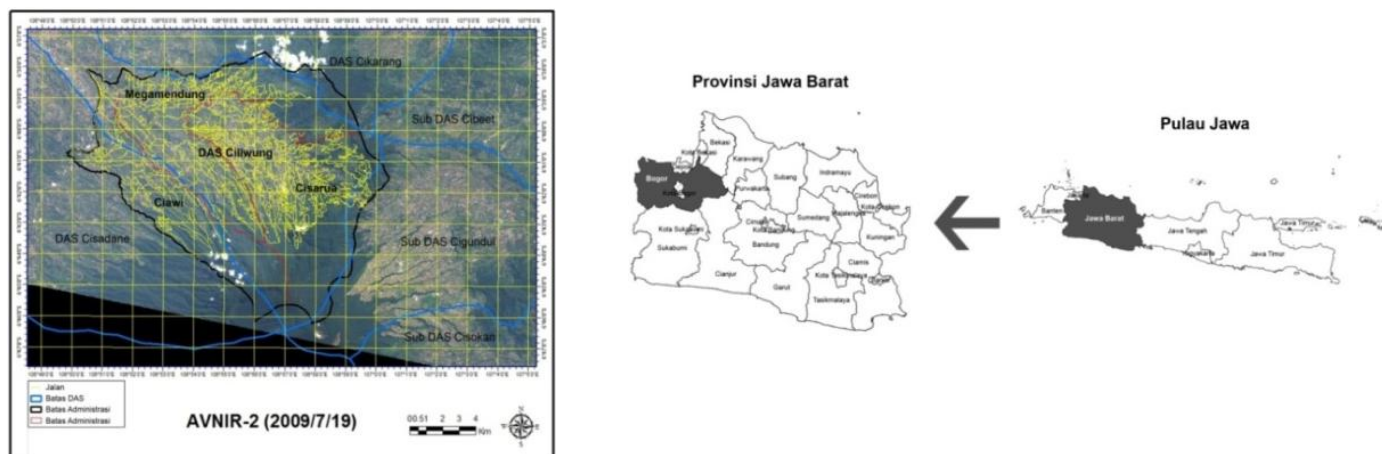

Gambar 1. Lokasi Penelitian (Kecamatan Ciawi, Megamendung, Cisarua)

\subsection{Metode Penelitian}

\subsubsection{Analisis Biodiversitas}

Metode analisis yang digunakan adalah analisis spasial dengan teknik overlay. Analisis ini dilakukan terhadapenam indikator yang berpengaruh pada keberlanjutan biodiversitas di suatu wilayah.Keenam indikator tersebut dispasialkan dalam bentuk peta biner yang dibagi menjadi grid-grid berukuran $100 \mathrm{~m} \times 100 \mathrm{~m}$. Dasar dari pemilihan ukuran grid ini adalah berdasarkan luasan desa terkecil di wilayah penelitian. Diperlukan klasifikasi ulang terhadap data spasial karena terdapat perbedaan satuan data dan skala pengukuran (Pereira et al., 1993). Langkah pertama dalam proses analisis nilai biodiversitas tersebut adalah melakukan kode ulang (recode) terhadap semua kriteria ke dalam kode biner, yaitu 0 atau 1 . Kode 1 mengindikasikan adanya kriteria yang terpenuhi dan kode 0 mengindikasikan tidak adanya kriteria yang terpenuhi. Seluruh proses recode dilakukan dengan menggunakan program ERDAS Imagine 9.1.

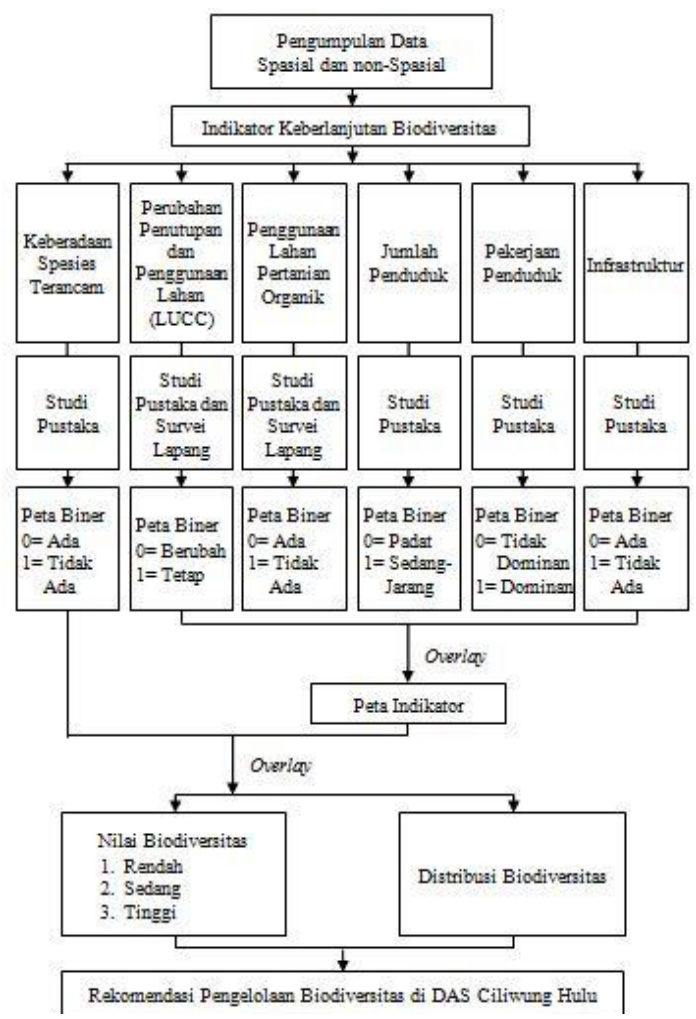

Gambar 2. Bagan Alur Penelitian 


\subsubsection{Keberadaan Spesies Terancam (Threatened Species)}

Dalam mendeteksi keberadaan spesies terancam yang terdapat di lokasi penelitian, diperlukan data jenis flora maupun fauna yang diperoleh melalui studi pustaka. Selain itu, diperlukan peta distribusi flora maupun fauna serta peta batas kawasan konservasi yang ada di lokasi penelitian. Selanjutnya dilakukan pengecekan keberadaan flora dan fauna yang ada dengan status flora dan fauna berdasarkan IUCN Red List Categories dan Peraturan Menteri Kehutanan Nomor 57 tahun 2008 tentang Arahan Strategis Konservasi Spesies Nasional. Jika di suatu area yang dispasialkan dalam grid terdapat flora maupun fauna dengan status terancam, maka akan diberi nilai 1. Sedangkan area yang tidak terdapat flora maupun fauna dengan status terancam akan diberi nilai 0 .

\subsubsection{Perubahan Penutupan dan Penggunaan Lahan}

Perubahan penutupan dan penggunaan lahan diperoleh dari perbandingan Peta Penutupan Lahan DAS Ciliwung Hulu tahun 2002 dengan Peta Penutupan Lahan DAS Ciliwung Hulu tahun 2009. Semakin tinggi tingkat perubahan lahan terbuka menjadi terbangun di wilayah penelitian, maka diasumsikan terdapat penurunan tingkat biodiversitas dan mengancam keberlangsungannya. Jika di suatu area yang dispasialkan dalam grid tidak terdapat perubahan lahan menjadi lahan terbangun (tetap ruang terbuka hijau), maka akan diberi nilai 1 . Sedangkan area yang terdapat perubahan lahan menjadi lahan terbangun akan diberi nilai 0 .

\subsubsection{Intensitas Penggunaan Lahan Pertanian Organik}

Lahan pertanian organik difokuskan menjadi indikator keberlanjutan biodiversitas. Menurut Liu et al. (2013), lahan pertanian organik dapat mendukung keberlanjutan biodiversitas dibandingkan lahan pertanian biasa yang menggunakan berbagai macam bahan kimia. Dalam mendeteksi penggunaan lahan pertanian organik di lokasi penelitian, dilakukan survei lapang ke masing-masing desa yang memiliki lahan pertanian organik. Data mengenai daftar desa yang memiliki lahan pertanian organik diperoleh melalui wawancara dengan pihak Gapoktan (Gabungan Kelompok Tani) masing-masing kecamatan dan pihak UPT (Unit Pelaksana Teknis) Pertanian. Jika di suatu area yang dispasialkan dalam grid terdapat lahan pertanian organik, maka akan diberi nilai 1. Sedangkan area yang tidak terdapat lahan pertanian organik akan diberi nilai 0 .

\subsubsection{Jumlah Penduduk}

Tekanan penduduk terhadap suatu wilayah dicerminkan oleh parameter kepadatan penduduk. Standar kepadatan penduduk di suatu wilayah mengacu pada formula tipologi kerentanan penduduk terhadap lahan (Paimin et al., 2012), yaitu: (a) Wilayah Padat, memiliki kepadatan penduduk > $400 \mathrm{jiwa} / \mathrm{km}^{2}$; (b) Wilayah Sedang, memiliki kepadatan penduduk 250 - 400 jiwa/km²; dan (c) Wilayah Jarang, memiliki kepadatan penduduk < $250 \mathrm{jiwa} / \mathrm{km}^{2}$. Dalam mendeteksi kepadatan penduduk di lokasi penelitian, diperlukan data jumlah penduduk yang diperoleh melalui studi pustaka. Jika di suatu area yang dispasialkan dalam grid termasuk dalam kategori wilayah dengan tingkat kepadatan penduduk sedang dan jarang, maka akan diberi nilai 1 . Sedangkan area yang termasuk dalam kategori wilayah dengan tingkat kepadatan penduduk padat akan diberi nilai 0 . 


\subsubsection{Pekerjaan Penduduk}

Menurut Paimin et al. (2012), jenis pekerjaan di bidang pertanian memiliki skor lebih tinggi dibandingkan dengan jenis pekerjaan lainnya. Jenis pekerjaan di bidang pertanian diasumsikan memiliki peran positif terhadap keberadaan biodiversitas. Semakin tinggi jumlah penduduk yang memiliki pekerjaan di bidang pertanian, maka semakin tinggi biodiversitas yang ada khususnya agrobiodiversitas. Dalam mendeteksi jenis pekerjaan penduduk di lokasi penelitian, diperlukan data struktur ekonomi penduduk yang diperoleh melalui studi pustaka. Jika di suatu area yang dispasialkan dalam grid dominan penduduknya memiliki pekerjaan di sektor pertanian, maka akan diberi nilai 1. Sedangkan area yang penduduknya tidak dominan atau bahkan tidak terdapat penduduk yang memiliki pekerjaan di sektor pertanian akan diberi nilai 0 .

\subsubsection{Infrastruktur}

Perkembangan pembangunan infrastruktur memiliki dampak terhadap keberadaan dan keberlanjutan biodiversitas di suatu wilayah. Semakin tinggi tingkat pembangunan infrastruktur, maka diasumsikan semakin rendah biodiversitas yang ada. Dalam mendeteksi infrastruktur di lokasi penelitian, diperlukan data infrastruktur yang diperoleh melalui studi pustaka dan dilakukan survei lapang. Jika di suatu area yang dispasialkan dalam grid tidak terdapat infrastruktur, maka akan diberi nilai 1. Sedangkan area yang terdapat infrastruktur akan diberi nilai 0 .

Tahap selanjutnya adalah melakukan overlay peta biner yang dihasilkan dari keenam indikator keberlanjutan biodiversitas. Dari hasil overlay keenam peta biner tersebut, diketahui nilai kumulatif dari seluruh indikator. Nilai kumulatif tersebut dibagi ke dalam 3 kategori, yaitu (1) rendah (terdapat 1-2 kriteria), (2) sedang (terdapat 3-4 kriteria), dan (3) tinggi (terdapat 5-6 kriteria). Metode ini pernah digunakan untuk mengidentifikasi area yang berpotensi sebagai area perlindungan di DAS Ciliwung Hulu oleh Syartinilia et al. pada tahun 2006. Namun, untuk indikator keberadaan spesies terancam, dijadikan sebagai indikator utama dalam menilai biodiversitas. Oleh karena itu, jika di suatu area yang dispasialkan dalam grid terdapat flora maupun fauna dengan status terancam, maka akan dikategorikan ke dalam nilai biodiversitas tinggi. Kategori nilai tersebut digunakan sebagai dasar penyusunan rekomendasi pengelolaan biodiversitas untuk jasa lanskap di DAS Ciliwung Hulu.

\section{Hasil dan Pembahasan}

\subsection{Hasil}

\subsubsection{Gambaran Situasional}

Lokasi penelitian ini terletak di DAS Ciliwung Hulu dan termasuk ke dalam kawasan Bopunjur yang meliputi 25 desa di Kecamatan Ciawi, Megamendung, dan Cisarua dengan luas wilayah sebesar $14.324 \mathrm{Ha}$. Secara umum, penutupan lahan di kawasan ini terbagi ke dalam tujuh kelas, yaitu hutan, perkebunan, semak belukar, sawah, ladang, permukiman, dan badan air. Kegiatan ekonomi masyarakat cenderung beragam dan terus mengalami pergeseran dari sektor pertanian ke sektor non-pertanian. Sektor pariwisata memiliki peran cukup penting dalam meningkatkan ekonomi masyarakat. 


\subsubsection{Indikator Keberlanjutan Biodiversitas}

\subsubsection{Keberadaan Spesies Terancam (Threatened Species)}

Dari 25 desa yang terdapat di lokasi penelitian, hanya 6 desa yang terdeteksi memiliki spesies terancam, yaitu Desa Sukaresmi, Sukagalih, Kuta, Citeko, Cibeureum, dan Tugu Selatan. Keenam desa tersebut terletak di Kecamatan Megamendung dan Cisarua. Berdasarkan Peta Indikator Keberadaan Spesies Terancam (Gambar 3), dapat diketahui bahwa luas area yang memiliki dan tidak memiliki spesies terancam mencapai $5.334 \mathrm{Ha}$ atau sekitar $37,24 \%$ dari luas total dan $8.626 \mathrm{Ha}$ atau sekitar $60,22 \%$ dari luas total.

\subsubsection{Perubahan Penutupan dan Penggunaan Lahan (LUCC)}

Dari 25 desa yang terdapat di lokasi penelitian, keseluruhannya terdeteksi mengalami perubahan penutupan dan penggunaan lahan. Berdasarkan Peta Indikator Perubahan Penutupan dan Penggunaan Lahan (Gambar 3), dapat diketahui bahwa area yang mengalami perubahan lahan (terbuka-terbangun) dan area yang tidak mengalami perubaHan menjadi lahan terbangun (tetap terbuka) mencapai $2.635 \mathrm{Ha}$ atau sekitar $18,40 \%$ dari luas total dan $11.325 \mathrm{Ha}$ atau sekitar $79,06 \%$ dari luas total.

\subsubsection{Intensitas Penggunaan Lahan Pertanian Organik}

Dari 25 desa yang terdapat di lokasi penelitian, hanya 4 desa yang memiliki lahan pertanian organik, yaitu Desa Cipayung Datar, Cibeureum, Tugu Selatan, dan Batu Layang. Keempat desa tersebut terletak di Kecamatan Megamendung dan Cisarua. Berdasarkan Peta Indikator Penggunaan Lahan Pertanian Organik (Gambar 3), dapat diketahui bahwa luas area yang terdapat dan tidak terdapat lahan pertanian organik mencapai $365 \mathrm{Ha}$ atau sekitar 2,55\% dari luas total dan $13.586 \mathrm{Ha}$ atau sekitar $94,85 \%$ dari luas total.

\subsubsection{Jumlah Penduduk}

Dari 25 desa yang terdapat di lokasi penelitian, keseluruhannya terdeteksi memiliki area dengan kepadatan penduduk sedang-jarang dan padat. Berdasarkan Peta Indikator Jumlah Penduduk (Gambar 3), dapat diketahui bahwa area dengan kepadatan penduduk sedang-jarang mencapai $11.325 \mathrm{Ha}$ atau sekitar $79,06 \%$ dari luas total dan area dengan kepadatan penduduk padat mencapai $2.635 \mathrm{Ha}$ atau sekitar $18,40 \%$ dari luas total.

\subsubsection{Pekerjaan Penduduk}

Dari 25 desa yang terdapat di lokasi penelitian, hanya 8 desa yang pekerjaan penduduknya dominan di bidang pertanian, yaitu Desa Sukagalih, Sukakarya, Sukamanah, Sukamaju, Sukamahi, Megamendung, Cibeureum, dan Cilember. Kedelapan desa tersebut terletak di Kecamatan Megamendung dan Cisarua. Berdasarkan Peta Indikator Pekerjaan Penduduk (Gambar 3), dapat diketahui bahwa luas area dengan pekerjaan penduduk dominan dan tidak dominan di bidang pertanian mencapai 6.277 Ha atau sekitar 43,82\% dari luas total dan $7.683 \mathrm{Ha}$ atau sekitar $53,64 \%$ dari luas total.

\subsubsection{Infrastruktur}

Dari 25 desa yang terdapat di lokasi penelitian, keseluruhannya terdeteksi memiliki infrastruktur. Berdasarkan Peta Indikator Infrastruktur (Gambar 3), dapat diketahui bahwa 
area yang memiliki dan tidak memiliki infrastruktur mencapai 7.668 Ha atau sekitar 53,53\% dari luas total dan $6.292 \mathrm{Ha}$ atau sekitar $43,93 \%$ dari luas total.

\subsubsection{Keseluruhan Indikator}

Dari 25 desa yang terdapat di lokasi penelitian, sebanyak 12 desa terdeteksi memiliki area dengan kategori nilai biodiversitas tinggi, 19 desa memiliki area dengan kategori nilai biodiversitas sedang, dan seluruh desa memiliki area dengan kategori nilai biodiversitas rendah. Berdasarkan Peta Nilai dan Distribusi Biodiversitas (Gambar 4), dapat diketahui bahwa area dengan kategori nilai biodiversitas tinggi, sedang, dan rendah mencapai $6.121 \mathrm{Ha}$ atau sekitar $42,73 \%$ dari luas total, $5.204 \mathrm{Ha}$ atau sekitar $36,33 \%$ dari luas total, dan $2.635 \mathrm{Ha}$ atau sekitar $18,40 \%$ dari luas total.

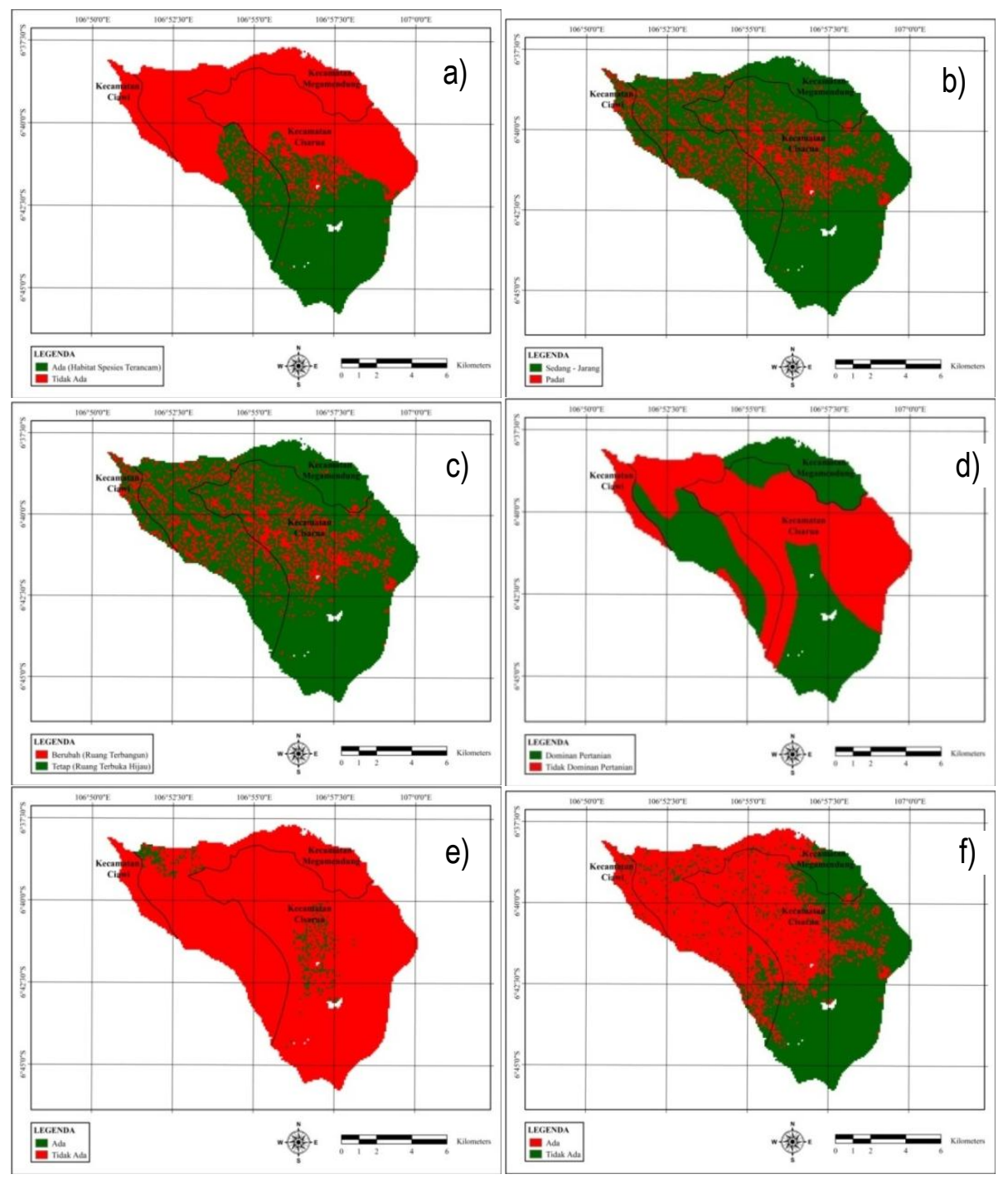

Gambar 3. Peta Indikator Nilai Biodiversitas (a) Indikator Keberadaan Spesies Terancam),

(b) Indikator Perubahan Penutupan dan Penggunaan Lahan, (c) Indikator Pengunaan

Lahan Pertanian Organik, (d) Indikator Jumlah Penduduk, (e) Indikator Pekerjaan Penduduk, dan (f) Indikator Infrastruktur 
Area nilai biodiversitas tinggi yang terluas terdapat di Desa Cibeureum (Kecamatan Cisarua), yaitu sebesar $2.555 \mathrm{Ha}$ atau sekitar $17,84 \%$ dari luas total. Untuk area nilai biodiversitas sedang yang terluas terdapat di Desa Tugu Utara (Kecamatan Cisarua), yaitu sebesar 1.199 Ha atau sekitar 8,37\% dari luas total. Sementara itu, area nilai biodiversitas rendah yang terluas terdapat di Desa Kopo (Kecamatan Cisarua), yaitu sebesar $287 \mathrm{Ha}$ atau sekitar $2 \%$ dari luas total.

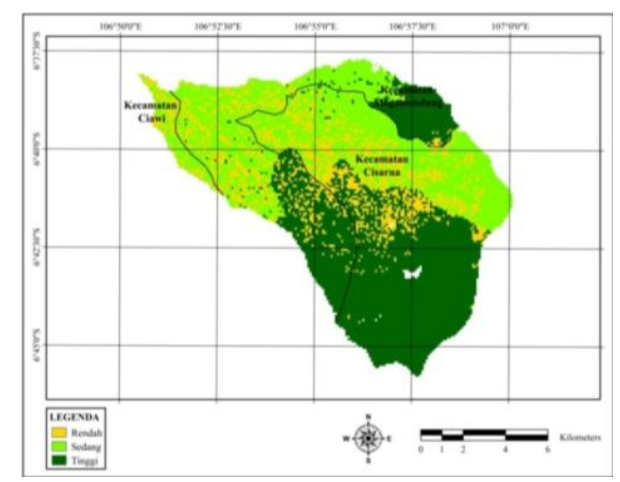

Gambar 4. Peta Nilai dan Distribusi Biodiversitas

\subsection{Pembahasan}

Berdasarkan hasil identifikasi nilai biodiversitas, Kecamatan Cisarua dan Megamendung merupakan wilayah terluas pertama dan kedua yang memiliki area nilai biodiversitas tinggi.Hal ini menunjukkan bahwa kondisi biodiversitas yang ada di wilayah ini masih terjaga dengan baik. Sementara itu, Kecamatan Ciawi diketahui tidak memiliki area nilai biodiversitas tinggi. Hal ini menunjukkan bahwa kondisi biodiversitas yang ada di wilayah ini kurang terjaga dengan baik dan berada pada kondisi rentan.

Berdasarkan hasil identifikasi pada tiga kecamatan di lokasi penelitian, dapat diketahui bahwa ketiga kecamatan tersebut memiliki struktur lanskap yang berbeda-beda. Perbedaan struktur lanskap tersebut dapat berpengaruh pada kondisi biodiversitas di lanskap tersebut. Perubahan atau gangguan yang terjadi, baik diakibatkan oleh alam maupun manusia dapat mengubah struktur suatu lanskap.Selain itu, diketahui bahwa sebagian besar area dengan kategori nilai biodiversitas tinggi berada di DAS Ciliwung Hulu bagian atas, tepatnya di Kecamatan Cisarua. Wilayah yang memiliki area dengan kategori nilai biodiversitas tinggi dapat dicirikan oleh heterogenitas struktur lanskapnya, dimana heterogenitas merupakan kondisi/keadaan yang merefleksikan kompleksitas secara spasial pada suatu lanskap yang dibentuk oleh interaksi antara komponen biotik dan abiotik yang beragam. Menurut Dyke (2003), dalam suatu lanskap yang heterogen, biasanya terdapat keragaman dan kekayaan jenis spesies, baik flora maupun fauna. Suatu wilayah dengan heterogenitas tinggi cenderung memiliki kualitas lanskap yang lebih baik dibandingkan wilayah dengan heterogenitas rendah. Semakin tinggi tingkat heterogenitas suatu wilayah, maka semakin stabil wilayah tersebut dari gangguan yang datang. Selain itu, semakin heterogen suatu lanskap, maka daya dukung lanskap tersebut untuk menopang populasi dan aktivitas di dalamnya akan semakin besar juga. 
Semakin ke arah DAS Ciliwung Hulu bagian bawah, terdapat kecenderungan penurunan nilai biodiversitas. Wilayah yang memiliki area dengan kategori nilai biodiversitas sedang dapat dicirikan oleh struktur lanskap dengan tingkat heterogenitas sedang. Suatu wilayah dengan heterogenitas sedang ini cenderung memiliki kualitas lanskap yang cukup baik. Namun, diperlukan upaya untuk melindungi dan meningkatkan kualitasnya. Wilayah yang memiliki area dengan kategori nilai biodiversitas rendah dapat dicirikan oleh struktur lanskap yang mendekati kondisi homogen. Homogenitas merupakan kondisi/keadaan yang merefleksikan keseragaman suatu lanskap. Menurut Forman dan Godron (1984), lanskap homogen disusun oleh unsur-unsur atau elemen yang seragam dan cenderung memiliki biodiversitas yang rendah. Semakin homogen suatu lanskap, maka semakin rentan lanskap tersebut terhadap gangguan yang terjadi. Lahan yang homogen akan memiliki daya dukung yang cenderung lebih kecil dibandingkan lahan yang heterogen. Sebagian lanskap yang homogen disebabkan oleh manusia. Penurunan populasi dan kepunahan dapat disebabkan oleh lanskap yang homogen. Jika terjadi suatu gangguan dalam suatu lanskap yang homogen, maka kemungkinan rusaknya lanskap, penurunan kualitas lanskap, bahkan kepunahan seluruh biodiversitas yang terdapat pada lanskap tersebut akan semakin besar.

Sebagian besar area nilai biodiversitas pada ketiga kecamatan di lokasi penelitian memiliki luasan yang relatif kecil dan terpisah-pisah satu sama lainnya. Hal ini mengindikasikan adanya fragmentasi pada area tersebut. Fragmentasi lanskap merupakan perubahan kondisi lanskap yang mulanya berupa lahan yang luas, kemudian terpecahpecah menjadi beberapa patch baru yang dapat menyebabkan terputusnya hubungan aliran energi atau material antar patch baru tersebut. Melalui analisis spasial, fragmentasi lanskap tersebut menjadi lebih mudah dideteksi serta dapat diperkirakan dampak yang ditimbulkannya. Fragmentasi dapat diakibatkan oleh proses alami maupun aktivitas manusia yang ditandai oleh adanya perubahan penutupan dan penggunaan lahan. Menurut Farina (1998), fragmentasi merupakan faktor utama yang dapat menekan keberlanjutan biodiversitas yang terdapat di suatu area atau wilayah. Semakin besar tingkat fragmentasi di suatu area atau wilayah, maka semakin besar tekanan terhadap biodiversitas yang ada di dalamnya. Menurut Forman dan Godron (1984), manusia memiliki peran penting dalam melakukan perubahan pada suatu lanskap. Manusia dapat mengembangkan lahan dengan tiga hal, yaitu (1) sejalan dengan perubahan lanskap yang terjadi secara alami, (2) mengubah lanskap sesuai dengan kebutuhannya, dan (3) melakukan agregasi. Jika tidak dikendalikan dengan baik, maka peran manusia dalam pengembangan lanskap akan berdampak negatif terhadap keberlanjutan biodiversitas.

\subsubsection{Rekomendasi Pengelolaan}

Dari hasil studi terhadap nilai dan distribusi biodiversitas, dapat disusun beberapa rekomendasi untuk pengelolaan biodiversitas di DAS Ciliwung Hulu, yaitu:

1. Penyelarasan wilayah DAS Ciliwung khususnya bagian hulu yang memiliki luas 14.324 Hadengan wilayah Administrasi Daerah (Kecamatan Ciawi, Megamendung, dan Cisarua) melalui koordinasi antar pihak terkait sehingga dapat mempermudah sistem pengelolaan dan pemantauan kualitas lanskap beserta biodiversitasnya. 
2. Perlu dilakukan upaya perlindungan melalui pendekatan hukum pada ketiga kecamatan (Cisarua, Megamendung, dan Ciawi) khususnya area dengan kategori nilai biodiversitas tinggi yang memiliki luas $6.121 \mathrm{Ha}$. Upaya perlindungan tersebut dapat dilakukan dengan beberapa cara, yaitu:

a. Peningkatan penegasan hukum mengenai penetapan kawasan hutan, perubahan status hutan, dan fungsi kawasan hutan sesuai dengan Keputusan Menteri Kehutanan Nomor 70 tahun 2001.

b. Pembatasan secara ketat terhadap kegiatan atau aktivitas yang dapat menyebabkan perubaHan penutupan dan penggunaan lahan sesuai dengan Rencana Tata Ruang Wilayah (RTRW) dan khususnya Rencana Detail Tata Ruang (RDTR) yang telah ditetapkan.

c. Kewajiban penanaman kembali di lahan Hak Guna Usaha yang terlantar.

3. Perlu dilakukan upaya rehabilitasi laHan pada ketiga kecamatan (Cisarua, Megamendung, dan Ciawi) khususnya area dengan nilai biodiversitas rendah, sedang, dan tinggi yang mengalami fragmentasi. Upaya rehabilitasi lahan tersebut dapat dilakukan melalui penerapangreen roof dan vertical greenery serta reboisasi dan penghijauan lahan terbengkalai serta area perlindungan.

4. Mempertahankan kawasan perkebunan teh yang dapat berfungsi sebagai buffer zone bagi kawasan Taman Nasional Gunung Gede Pangrango (TNGGP), Cagar Alam serta Taman Wisata Alam Telaga Warna.

5. Meningkatkan dan mempertahankan sistem insentif (pengurangan hingga pembebasan pajak) bagi pihak yang mendukung pelestarian biodiversitas dan sistem disinsentif (pembongkaran bangunan dan lipatganda jumlah pajak) bagi pihak yang menyebabkan kerusakan lanskap dan penurunan biodiversitas.

6. Melakukan sosialisasi secara periodik tentang biodiversitas, peran, dan manfaatnya terhadap keseimbangan alam pada berbagai pihak terkait seperti pemerintah, swasta, dan masyarakat. Sosialisasi tersebut dapat dilakukan dalam bentuk seminar, workshop, maupun pelatihan khusus mengenai biodiversitas dan ekosistemnya. Hal ini bertujuan untuk meningkatkan kesadaran akan pentingnya pelestarian biodiversitas.

\section{Simpulan}

Berdasarkan hasil analisis nilai biodiversitas di DAS Ciliwung Hulu, dapat diidentifikasi bahwa terdapat $6.121 \mathrm{Ha}$ area nilai biodiversitas tinggi, $5.204 \mathrm{Ha}$ area nilai biodiversitas sedang, dan $2.635 \mathrm{Ha}$ area dengan kategori nilai biodiversitas rendah. Dari hasil identifikasi distribusi biodiversitas di lokasi penelitian, diketahui bahwa semakin ke arah DAS Ciliwung Hulu bagian bawah terdapat kecenderungan penurunan nilai biodiversitas, yaitu dari Kecamatan Cisarua, Megamendung, dan Ciawi. Hal ini dipengaruhi oleh terbatasnya ketersediaan lahan terbuka, tingginya tingkat perubahan penutupan dan penggunaan lahan, pesatnya pembangunan infrastruktur, dan faktor sosial ekonomi seperti peningkatan jumlah penduduk dan struktur ekonomi yang dilihat dari jenis pekerjaan utama penduduk. Beberapa rekomendasi pengelolaan biodiversitas yang dihasilkan, yaitu (1) 
menyelaraskan wilayah DAS dan administrasi daerah, (2) melakukan perlindungan area nilai biodiversitas melalui pendekatan hukum, (3) melakukan rehabilitasi lahan pada area nilai biodiversitas yang mengalami fragmentasi, (4) mempertahankan kawasan perkebunan teh yang berfungsi sebagai buffer zone bagi kawasan TNGGP dan kawasan Telaga Warna, (5) memberlakukan sistem insentif dan disinsentif bagi pihak terkait, dan (6) melakukan sosialisasi secara periodik terkait biodiversitas dan jasa lanskap.

\section{Daftar Pustaka}

Badan Perencanaan Pembangunan Nasional [BAPPENAS] 2004. Wilayah Kritis Keanekaragaman Hayati di Indonesia: Instrumen Penilaian dan Pemindaian Indikatif/Cepat bagi Pengambil Kebijakan. Jakarta: Direktorat Pengendalian Sumberdaya Alam dan Lingkungan Hidup.

Curry, G.B. \& Humphries, C.J. 2007. Biodiversity Databases: Techniques, Politics, and Applications. CRC Press, New York.

Dyke, F.V. 2003. Conservation Biology: Foundations, Concepts, Applications. McGraw-Hill Companies, Inc, New York.

Forman RTT dan Godron M. 1986. Landscape Ecology. New York (US): John Wiley and Sons.

Liu, Y., Duan, M., and Yu, Z. 2013. Agricultural Landscapes and Biodiversity in China. Agriculture, Ecosystems and Environment, 166: 46-54.

Nunes, P.A.L.D., Van den Bergh, J.C.J.M., and Nijkamp, P. 2003. The Ecological Economics of Biodiversity: Methods and Policy Applications. Edward Elgar Publishing, Inc, CheltenHam.

Paimin, Pramono, I.B., Purwanto, dan Indrawati, D.R. 2012. Sistem Perencanaan Pengelolaan Daerah Aliran Sungai. Pusat Penelitian dan Pengembangan Konservasi dan ReHabilitasi (P3KR), Bogor.

Rewards for Use of and Shared Investment in Pro-Poor Environmental Services[RUPES]. 2009. Gagasan Kebijakan: Konsep Jasa Lingkungan dan Pembayaran Jasa Lingkungan di Indonesia. Tersedia pada: http:/l http://www.worldagroforestry.org/sea/Publications/files/leaflet/LE0160-09.PDF(diunduh 2013 Januari 27).

Sutopo, M.F. 2011. Pengembangan Kebijakan Pembayaran Jasa Lingkungan dalam Pengelolaan Air Minum (Studi Kasus DAS Cisadane Hulu) [disertasi]. Sekolah Pasca Sarjana Institut Pertanian Bogor, Bogor.

Syartinilia, Arifin, H.S., Prasetyo, L.B. and Tsuyuki, S. 2006. Identification of Potential Protection Area Using GIS and Remote Sensing: A Case Study in The Upper Stream of Ciliwung Watershed of West Java, Indonesia. Formath Kyoto, 2005. Forest Resources and Mathemathical Modeling (Eds: Atsushi Yoshimo-to, Hiroshi Kondoh, \& Takuya Hisroshima). Japan Society of Forest Planning Press. Utsunomiya, Japan. Vol.5: 209219.

Verburg, P.H., Lesschen, J.P., Koomen, E., and Soba, M.P. 2011. Simulating Land Use Policies Targeted to Protect Biodiversity with the CLUE-Scanner Model. IGI Global. doi: 10.4018/978-1-60960-619-0.ch006. 